\title{
Spatial distribution of agro-input centers and their accessi- bility to farmers in Oyo State, Nigeria
}

\author{
A. OYEGBAMI*, A.M. OMOTAYO, S.O. APANTAKU, K.O. ADUBI \& E. FABUSORO \\ (A.O.: Institute of Agricultural Research and Training, Moor Plantation, \\ Ibadan Oyo State, Nigeria; A.M.O, S.O.A \& E.F.: Department of Agricultural \\ Extension and Rural Development, Federal University of Agriculture. Abeokuta, \\ Ogun State, Nigeria; K. O. A .: Department of Home Management and \\ Extension, Federal University of Agriculture, Abeokuta, Ogun State, Nigeria) \\ *Corresponding author's email:titi_oyegbami@yahoo.com
}

\begin{abstract}
The study investigated the spatial distribution of agro-input centers and related it to farmers' accessibility. Data were generated through a survey of 320 farmers randomly selected from the four agricultural zones of Oyo State Agricultural Development Programme (OYSADEP). The socio-economic characteristics of respondents were described using frequency counts and percentages. Inferential statistics such as chi-square was used to test the hypotheses. Geographic Information System (GIS) software (ArcView 9.3) was used to map locations and analyse distances and multiple buffers were developed around input centers to determine farmers' accessibility. Results from the study show that inputs like fertilizer (65\%), agro-chemicals $(94.38 \%)$, and planting materials like seeds and stems $(90.63 \%)$ were majorly procured from private input centers. Majority (74.37\%) of the farmers interviewed travel more than $15 \mathrm{~km}$ to procure input from government established input centers. Chi-square results showed significant relationship between sex $\left(\chi^{2}=29.51, \mathrm{P}=0.05\right)$, marital status $\left(\chi^{2}=10.97, \mathrm{P}=0.00\right)$, income $\left(\chi^{2}=32.55, \mathrm{P}=0.00\right)$ and farm size $\left(\chi^{2}=14.73, \mathrm{P}=0.00\right)$. Improvement in agricultural output will depend to some extent on farmers' access to agro-input centers. The government should establish agro-input input centers closer to farmers and make inputs available at subsidized rates; this will make them affordable to farmers and increase agricultural production.
\end{abstract}

Keywords: Agro-input; centers; accessibility; spatial; distribution.

Original scientific paper. Received 29 Jan 19; revised 02 Oct 19

\section{Introduction}

Agriculture employs nearly three-quarters of Nigeria's workforce, as is the case in most of Sub-Saharan Africa (SSA). Agriculture is the principal source of food and livelihood in Nigeria, making it a critical component of programs that seek to reduce poverty and attain food security in Nigeria (Philips et al., 2009). Nigeria is one of the largest countries in
Africa with a total geographic area of 923,768 square kilometers and an estimated population of about 167 million (NBS, 2014) and has a highly diversified agro-ecological condition which makes possible the production of a wide range of agricultural produce (Ofona et al., 2016).

Agricultural production in Nigeria has been declining over the years. The contribution

Ghana Jnl Agric. Sci. 55 (1), 22 - 33

GJAS is an Open Access Journal and distributed under the terms of the Creative Commons (CC) License [CC BY 4.0] 
of agriculture to Nigeria's Gross Domestic Product (GDP) decreases from about 60\% in the 1960 s to about $35 \%$ in 1990 (Central Bank of Nigeria, 1997). Several reasons have been adduced for this and a situation prominent among which is the neglect of the agricultural sector during the oil boom of the mid-1970s. Nigeria which was an exporter of agricultural produce became an importer of agricultural produce including food (Okorji, 2001). Nigeria has tried in various manners and has committed a lot of effort and resources to agricultural development. These efforts, however, have yielded quite below expectations as there is still poor commercialization of research findings. The case of the agricultural sector gives special concern as no country is truly free when it cannot feed its citizens.

Over the years, the agricultural sector has provided employment opportunities for the majority (over 70\%) of the nation's populace, especially those in rural areas (Ogbalubi \& Wokocha, 2013). Due to the significance of this sector to the economic development of the country, the government was able to introduce and implement quite a lot of policies and programmes aimed at improving the sector and unleashing its potentials in the country (Okunola, 2016). Some of these programmes and projects include; the National Accelerated Food Production Programme (NAFPP), Operation Feed the Nation (OFN), Directorate of Food, Roads and Rural Infrastructure (DFRRI), River Basin Development Authorities (RBDA), National Agricultural Land Development Authority (NALDA), Project coordinating Units (PCU), Agricultural Credit Scheme (ACGS), Green Revolution (GR), Agricultural Development Programme (ADP) (Oyegbami, 2014). In recent decades, the National Fadama Development Project, National Special Programme for
Food Security, Community and Social Development Projects, and the Agricultural Transformation Agenda (ATA) were also implemented among many others. These programmes and projects were implemented nationally to; increase land access through reforms, provide rural infrastructure, enhance credit access, and grant input subsidies and boost agricultural productivity.

The backbone of any agricultural revolution is the access of farmers to modern agricultural inputs. These agricultural inputs range from improved seeds, fertilizers and crop protection chemicals to machinery, irrigation and knowledge. Seeds are critical to successful crop production and inevitably, farm productivity and profitability. Fertilizer supplies nutrients to the soil that are essential for growth. Increased use of fertilizer and improved seeds are partially credited with the large increases in agricultural productivity growth in Asia during the Green Revolution in the 1960s. Irrigation is also essential for growth as it enables off-season farming, provides the potential for multiple harvests per year and brings additional land under cultivation. Crop protection chemicals (pesticides, herbicides, insecticides and fungicides) control weed species, harmful insects and plant diseases that afflict crops. Finally, technical knowledge and machinery enhance human labor effectiveness and increase farm productivity (FMARD, 2016).

African farmers face a variety of constraint including limited access to new agricultural technologies, agro-input, low productivity and weak markets (FMARD, 2016). Without adequate inputs, farmers often cannot meet the food needs of their own families, much less those of a rapidly growing population. Applied with the ultimate goal of maximizing agricultural productivity, agricultural inputs have a 
huge potential to scale-up and unlock agricultural productivity in Nigeria, most especially at such a crucial time in the development of the nation's agriculture landscape.

To feed themselves and their countries and to reduce poverty and malnutrition, farmers will need to shift from low yielding, extensive land practices to more intensive, higher-yielding practice, with increased use of improved seeds, fertilizers and other agricultural inputs. A wide communication gap between researchers, extension agents and farmers is also a problem while the production environment itself stands out among these constraints. Almost all information to support agriculture and rural development has a strong geographical context, particularly since it deals with the natural resource base over extensive areas (Kumar \& Misra, 2005). This underscores the importance of spatial influence on distribution and access to agro-input centers as recent studies have brought to view the vital potential of Geographic Information System (GIS) as a veritable tool in planning, execution, and management of projects targeted at developing the rural areas.

This study, therefore, examined the distribution of agro-input centers using GIS (Geographic Information System) approach to locate input centers and relate them to farmers' accessibility. The specific objectives of the study are:

1. to find out the socio-economic characteristics of farmers,

2. identify and describe the services rendered by agro-input centers to farmers,

3. spatially analyse the locations/distribution of agro-input centers and generate maps for spatial inference.
Hypothesis of the study

Ho1: There is no significant relationship between selected socio-economic characteristics and access to agro-input centers

\section{Materials and Methods}

\section{Study location}

Oyo State is one of the 36 states of the Federal Republic of Nigeria and covers a total of 27,249 square kilometers of land mass. Oyo State is located in the South-west geopolitical zone of Nigeria and is bounded in the south by Ogun State, in the North by Kwara State, in the West it is partly bounded by Ogun State and partly by the Republic of Benin while in the East by Osun state. It has 33 local government areas with Ibadan being the largest city in the States. It has for agricultural zones namely; Ibadan/ibarapa, Saki, Oyo and Ogbomoso zones. Oyo State has an equatorial climate with dry and wet season and relatively high humidity, average daily temperature ranges between $25^{\circ} \mathrm{C}(77.00 \mathrm{~F})$ and $350^{\circ} \mathrm{C}(95.00 \mathrm{~F})$ almost throughout the year. The vegetation pattern of Oyo State is that of rain forest in the South and guinea savannah in the North. Agriculture is the major source of income for a great number of people of Oyo State. The state is homogenous, comprising mainly people of the Yoruba ethnic group

\section{Sampling procedure}

Sampling was based on four agricultural zones of the state ADP. These are Ibadan/ Ibarapa, Ogbomosho, Oyo, and Saki zones. A multistage random sampling technique was used. Two Local Government Areas (LGAs) were randomly selected from each zone to give a total of eight LGAs. Six villages were randomly selected from each LGA to give a total of 48 villages and seven farmers 
were randomly selected from each village which gave a total of 336 respondents. 320 questionnaires were completed and these were used for analysis.

\section{Types of Data}

The data for this study were generated from three main sources: primary, secondary and spatial data. Primary data were obtained from respondents' socio-economic characteristics, services rendered to farmers by agro-input centers, and on accessibility to agro-input centers. The secondary data were obtained from Oyo State Agricultural Development Programme (ADP) on the location of farm service/government input-centers, location and names of villages. The spatial data were collected using GPS by identifying positions/coordinates of locations of farmers and agro-input centers.

\section{Measurement of variables}

Descriptive statistics such as frequency counts and percentages were employed for socio-economic characteristics of farmers, services rendered by agro-input centers were categorized as "Major services" and" Minor services", and grouped into percentages.

Accessibility to agro-input centers was determined using kilometer (distance) covered in getting to these centers. Chi-square analysis was used to test the hypothesis of this study at 0.05 and 0.01 level of significance

\section{GIS Analysis}

In GIS analyses, the excel Files were converted to DBF Files to serve as point data input to GIS. The DBF was loaded into Arc GIS and then converted to GIS data layers. These maps were produced using the various display methods available in the symbology of Arc GIS. For the computation of distance, all GIS layers were projected from geographic coordinates to Universal Transverse Mercator (UTM) projection. For buffering around locations to determine proximity to agro-input centres in the proximity analysis tools, the multiple buffer tool was used to buffer around the location at two levels of buffer (5 and $10 \mathrm{~km})$.

\section{Results and Discussion}

Socio-economic Characteristics

The socio-economic characteristics of respondents comprise the personal attribute of the respondents and some of their production characteristics as shown in Tables 1 and 2. The mean age was 53 years indicating that majority of the respondents were in their middle age. Though one might say that those in this age category are getting old, this implies that the aged are now left to do farm work and this may have a negative effect on agricultural productivity in the long run. Although some authors still refer to this age category as being within the economically active age category (FAO, 1997). Access to agro-input may also be affected by age, too old farmers may not be able to access agro-input when compared to the young ones. Yinnusa (1999) observed that these age brackets contain innovative, motivated and adaptive individuals. Omotayo (2011) submitted that one major problem with agricultural development in Nigeria is the ageing farm population without sustainable replacement. He argued that young people do not want to take on farming as a profession because of its inherent association with poverty. Very few $(3.44 \%)$ of the respondents were below the age of thirty years, majority $(77.81 \%)$ of the respondents were male and $92.50 \%$ were married.

The mean household size was 8 persons per household and this implies that there will be more hands to work on the farm. Reardon (1997) observed that family size affects the ability of the household to supply 
labour to the farm sector. He argued that families with multiple conjugal units supply more labour to the farm sector as sufficient family members remain in the home or the farm to meet the labour needs for subsistence. A little above sixty-four percent $(64.37 \%)$ of the farmers had one form of education or the other, education, according to Gordon and Craig (2001) increases skill level which may be required for some farming activities (chemical or fertilizer application) on the farm and drug administration in livestock farming. Education also has the advantage of giving farmers the ability to source information on improved technology and communicating the same to other farmers thus increasing awareness.

Furthermore, about three quarters (74.69\%) of the respondents practiced farming as their major occupation. According to Jibowo (2000) and Ironkwe (2006) farming is the major economic activity in rural areas. The respondents were also involved in other occupations such as agro-processing (15\%) trading $(6.88 \%)$, teaching $(0.63 \%)$, civil service $(0.94 \%)$ and handicraft $(1.88 \%)$. Ekong (2003), asserted that collective enterprise forms the basis of rural economy and that some rural people are engaged in retailed and petty trading, weaving and other handicraft and only a few tend to take these as sole occupations. Rather they tend to combine these with farming and a greater proportion of them are fulltime farmers.
TABLE 1

Socio-economic Characteristics of Respondents $(n=320)$

\begin{tabular}{|c|c|c|c|}
\hline Parameters & Frequency & Percentage & Mean(Mode) \\
\hline \multicolumn{4}{|l|}{ Age (years) } \\
\hline$<30$ years & 11 & 3.44 & \multirow{5}{*}{ 53years } \\
\hline $31-40$ years & 43 & 13.44 & \\
\hline $41-50$ years & 69 & 21.56 & \\
\hline $51-60$ years & 116 & 36.25 & \\
\hline$>60$ years & 91 & 28.44 & \\
\hline \multicolumn{4}{|l|}{ Sex } \\
\hline Male & 249 & 77.81 & \multirow[t]{2}{*}{ (Male) } \\
\hline Female & 71 & 22.19 & \\
\hline \multicolumn{4}{|l|}{ Marital Status } \\
\hline Married & 296 & 92.50 & \multirow{3}{*}{ (Married) } \\
\hline Single & 4 & 1.25 & \\
\hline Widowed & 20 & 6.25 & \\
\hline \multicolumn{4}{|l|}{ Household size } \\
\hline $1-3$ persons & 16 & 5.0 & \multirow{3}{*}{8 persons } \\
\hline 4-6 persons & 96 & 30.0 & \\
\hline $6-9$ persons & 106 & 33.13 & \\
\hline$>9$ persons & 99 & 30.94 & \\
\hline \multicolumn{4}{|l|}{ Educational status } \\
\hline No formal Education & 114 & 35.63 & \multirow{7}{*}{$\begin{array}{l}\text { (Noformal } \\
\text { education) }\end{array}$} \\
\hline Adult Education & 22 & 6.88 & \\
\hline Primary Education & 74 & 22.13 & \\
\hline Secondary Education & 48 & 15.00 & \\
\hline Tertiary Education & 43 & 13.44 & \\
\hline Others & 14 & 4.38 & \\
\hline \multicolumn{3}{|l|}{ Primary occupation } & \\
\hline Farming & 239 & 74.69 & \multirow{6}{*}{ (Farming) } \\
\hline Agro-processing & 48 & 15.00 & \\
\hline Trading & 22 & 6.88 & \\
\hline Teaching & 2 & 0.63 & \\
\hline Civil service & 3 & 0.94 & \\
\hline Handicraft & 6 & 1.88 & \\
\hline
\end{tabular}

Source: Field survey, 2013 
TABLE 2

Distribution of Respondents Based on Production Characteristics $(n=320)$

\begin{tabular}{|c|c|c|c|}
\hline Parameter & Frequency & $\begin{array}{l}\text { Per- } \\
\text { cent- } \\
\text { age }\end{array}$ & $\begin{array}{l}\text { Mean(- } \\
\text { Mode) }\end{array}$ \\
\hline \multicolumn{4}{|l|}{ Hectares cultivated (ha) } \\
\hline$<5$ & $\begin{array}{l}234 \\
62\end{array}$ & 73.13 & 4.35 \\
\hline $5.1-10$ & 24 & $\begin{array}{l}19.36 \\
7.50\end{array}$ & (Own \\
\hline$>10$ & $\begin{array}{l}283 \\
37\end{array}$ & 88.44 & farmland) \\
\hline Farm ownership & & 11.56 & \\
\hline Own farmland & 11 & & \\
\hline Do not own farmland & 34 & 2.80 & \\
\hline Income/annum & 65 & 10.90 & 214,000 \\
\hline$<\mathrm{N} 50,000$ & 36 & 20.31 & \\
\hline \$50,001-100,000 & 106 & 11.25 & \\
\hline$\$ 100,001-150,000$ & 59 & 33.13 & \\
\hline$\$ 150,001-200,000=$ & 9 & 18.44 & \\
\hline$\$ 200,001-250,000$ & & 2.81 & \\
\hline 250,001-300,000 & 42 & & (Not ac- \\
\hline$>\approx 300,00$ & 278 & 13.10 & cessible) \\
\hline Access to Credit & & 86.90 & \\
\hline Accessible & & & \\
\hline Not accessible & & & \\
\hline
\end{tabular}

Source: Field survey, 2013

Services rendered by agro-input centers

Table 3 shows the services rendered by agroinput centers to farmers. Based on the findings from the study, $61.88 \%$ of the farmers indicated that private input centers (PIC) provide more of tractor hiring service. Respondents indicated during Focus group discussion (FGD) that tractors from government input centers are not readily available during planting season and the farmers rely on the public input centers for tractor hiring than government input centre. Despite the fact that government input centers have the mandate to provide tractor hiring service, most of these centers in the study area are under-equipped and the fewer tractor available are released based on political patronage as submitted by the farmers. This shortcoming gives the private input centers opportunities to provide tractor hiring services to farmers at a relatively high cost which may affect the cost of agricultural production.

Fertilizer distribution according to the respondents is majorly $(65 \%)$ provided by private input centers. Carney (1998) opined that fertilizer perhaps comes closer to being a private good when compared to other agricultural input and farmers have always paid at least something for its use. Result from the study also shows that $77.50 \%$ of the respondents indicated that the supply of agrochemical and supply of planting materials such as cassava stems, yam setts, and seeds were majorly provided by the government input centers as submitted by $83.44 \%$ of the respondents. The dissemination of information to farmers especially as regard farming activities is the core responsibility of extension agents; this may be the reason why $93.13 \%$ of the respondents indicated that the provision of information is mostly provided by government input centers.

TABLE 3

Services rendered by agro-input centers to farmers $(n=320)$

\begin{tabular}{|c|c|c|c|c|}
\hline \multirow[t]{2}{*}{$\begin{array}{l}\text { Service } \\
\text { rendered }\end{array}$} & \multicolumn{2}{|c|}{ Public (Government) } & \multicolumn{2}{|c|}{$\begin{array}{l}\text { Private (owned by } \\
\text { individual) }\end{array}$} \\
\hline & $\begin{array}{l}\text { Major } \\
\text { services }\end{array}$ & $\begin{array}{l}\text { Minor } \\
\text { services }\end{array}$ & $\begin{array}{l}\text { Major } \\
\text { services }\end{array}$ & $\begin{array}{l}\text { Minor } \\
\text { services }\end{array}$ \\
\hline $\begin{array}{l}\text { Tractor } \\
\text { hiring }\end{array}$ & $58(18.13)$ & $262(81.86)$ & $198(61.88)$ & $122(38.13)$ \\
\hline $\begin{array}{l}\text { Fertilizer } \\
\text { distribution }\end{array}$ & $102(31.88)$ & $218(68.13)$ & $208(65.00)$ & $112(35.00)$ \\
\hline $\begin{array}{l}\text { Supply of } \\
\text { agro- } \\
\text { chemicals }\end{array}$ & $208(65.00)$ & 112(38.13) & $302(94.38)$ & $18(5.63)$ \\
\hline $\begin{array}{l}\text { Agro- } \\
\text { chemicals } \\
\text { application }\end{array}$ & $248(77.50)$ & $72(22.50)$ & $92(28.75)$ & $228(71.25)$ \\
\hline $\begin{array}{l}\text { Supply of } \\
\text { planting } \\
\text { materials }\end{array}$ & $267(83.44)$ & $53(16.56)$ & $290(90.63)$ & $30(9.36)$ \\
\hline $\begin{array}{l}\text { Provision of } \\
\text { information }\end{array}$ & $298(93.13)$ & $22(6.88)$ & $178(55.63)$ & $142(44.38)$ \\
\hline
\end{tabular}

*Multiple responses given $\quad * *$ Figures in parenthesis are in Percentages

Source: Field survey, 2013 
Location / Distribution of government input centers

Figure 1 is a map showing the location of government input centers, while Table 4 shows the distance covered by farmers to government input centers. Buffering was done using the proximity analysis tool in GIS and the distance covered by farmers to government input centers was calculated (Table 4). Majority (74.37\%) of the farmers had to cover a distance above $15 \mathrm{~km}$ before they could procure inputs from government input centers, Transport cost when added to the cost of input will increase the total amount spent on input. One can infer that government input centers, which are referred to as farm service centers of the ADP are not within the reach of majority of farmers. Idachaba (2006) reported that any supportive network of farm service centre should ensure that no farmer travels more than $15 \mathrm{~km}$ to procure needed farm inputs. Omotayo (2005) reported that proximity to service centers is commonly regarded as an important factor in access and usage and that physical accessibility to agroinput centers is determined by geographical location in relation to available service and facilities. Thus, the cost of total production can be reduced if farmers cover short distances to input.

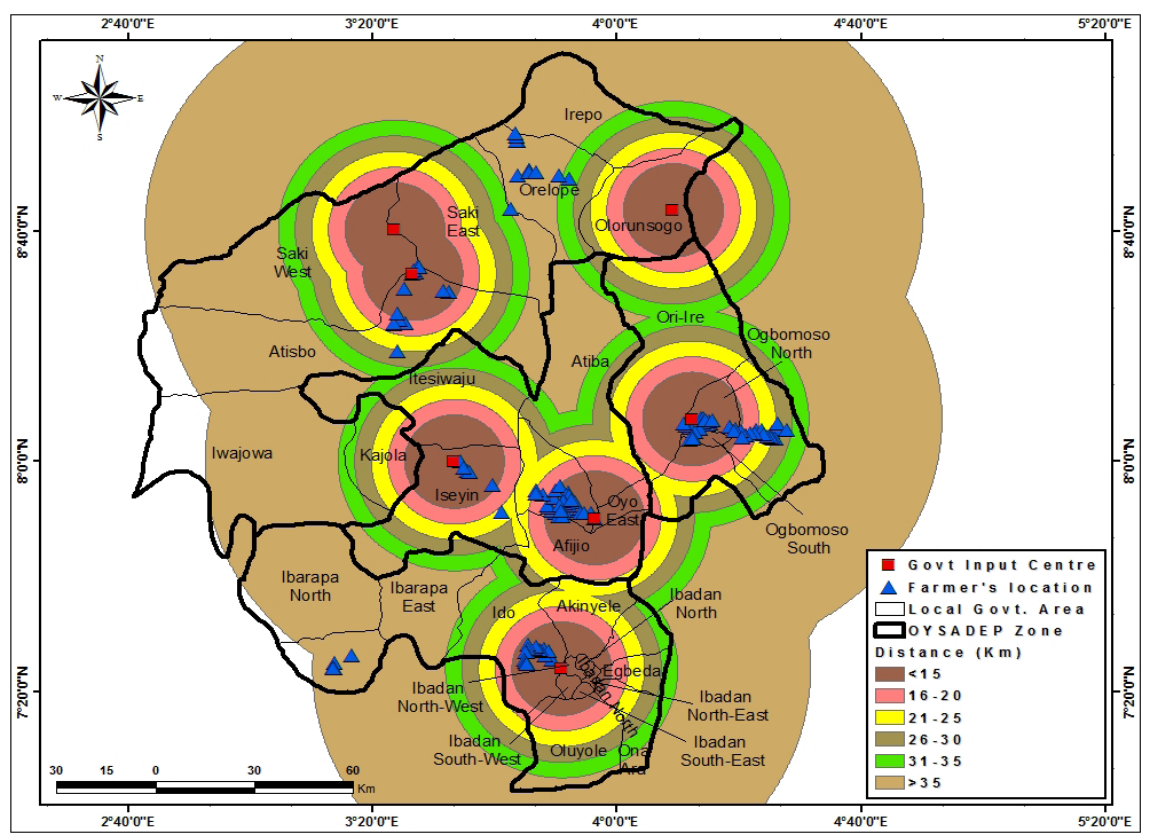

Fig. 1: Map of showing distance from farmers' location to government input center 
Spatial distribution of agro-input centers...

TABLE 4

Distribution of farmers based on distance from farmers'locations to government input centers

\begin{tabular}{lll}
\hline $\begin{array}{l}\text { Distance } \\
(\mathrm{km})\end{array}$ & Frequency & Percentage \\
\hline$<15$ & 82 & 25.63 \\
$15-20$ & 98 & 30.63 \\
$21-25$ & 16 & 5.00 \\
$26-30$ & 26 & 8.13 \\
$32-35$ & 56 & 17.50 \\
$>35$ & 41 & 13.13 \\
\hline
\end{tabular}

Source: Field survey, 2013

Location and distance covered by farmers to private agro-input centers

Private input centers though operated to make profits are established to provide input to farmers. They are probably located close to farmers for easy accessibility and prompt patronage. Figure 2 is a map showing the location of private input centers. The result in Table 5 shows that $50.94 \%$ of the respondents covered between $1-15 \mathrm{~km}$ to private input centers, while $23.31 \%$ covered between 16 $20 \mathrm{~km}$. Farmers that covered short distances are probably those that have input centers located close to their houses, or those that depend on neighbors or nearby village markets to get their inputs and therefore do not need to travel long distances. Respondents reported during the survey that travelling long distances (on road) to procure input especially from government established input centers is an additional cost on production and at times the inputs are not often available as to when needed using fertilizer as a test case. This they say adds to their production cost at the end of the day. Kihara (2008) submitted that it is common for rural farmers to travel long distances just for the opportunity to purchase seeds, herbicides or fertilizer. This may be the reason why farmers patronize private input centers more than government/farm service centers.

TABLE 5

Distance from farmers' locations to Private input centers

\begin{tabular}{lll}
\hline Distance $(\mathrm{km})$ & Frequency & Percentage \\
\hline$<15$ & 163 & 50.94 \\
$16-20$ & 81 & 25.31 \\
$21-25$ & 53 & 16.56 \\
$26-30$ & 23 & 7.19 \\
$31-35$ & 0 & 0.00 \\
$>35$ & 0 & 0.00 \\
\hline
\end{tabular}




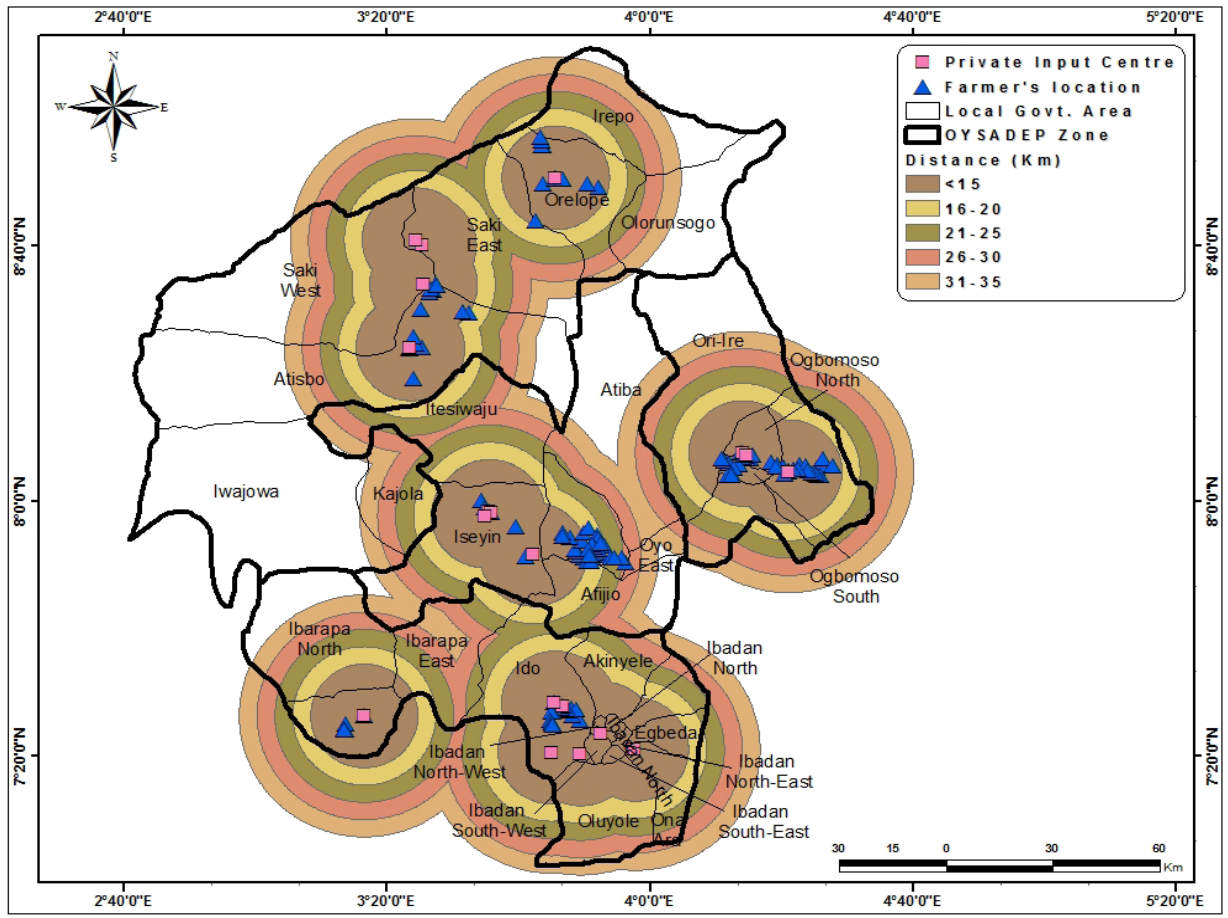

Fig.2 (jpeg): Map of showing distance from farmers' location to Private input centers

\section{Farmers Accessibility to Input Centers}

Distance to input centers, availability of needed input, affordability, ownership of means of transport and number of visits to input centers are some of the variables identified under accessibility for both government and private input centers. The results in Table 6 show that inputs are more available at private input centers than government input centers as submitted by $65.31 \%$ of the respondents. This is expected because the private input centers are out to make profits and will also want to satisfy their customers by making agro-inputs available as at when needed. About sixty-two percent $(61.86 \%)$ and $58.75 \%$ of the farmers affirmed that inputs are not affordable in terms of cost from both government and private input centers. Although, $61.88 \%$ claimed that private input centers are more accessible than government input centers since majority of the respondents cover less distance to get to private centers. Accessibility has two major expressions: potential access, which implies that service is available within the vicinity of a potential user, and revealed accessibility, which may be interpreted as use or utilization of services by the consumers. Ownership of the means of transportation is another factor that can affect the accessibility of farmers to input centers. A farmer with a means of transport may find it easier to procure input from private or government established centers than a farmer without any means of transport. The time of visits to input centers can also be used to 
measure accessibility. More than half (59.06\%) visit private input centers at last once in a month to procure inputs compared to $30.63 \%$ that visit government established centers. Locational accessibility is the most commonly recognized form of physical accessibility.

TABLE 6

Distribution of farmers based on accessibility and patronage to input centers

\begin{tabular}{lllll}
\hline \multirow{2}{*}{ Parameters } & \multicolumn{3}{l}{ Government input centers } & \multicolumn{2}{l}{ Private input centers } \\
\cline { 2 - 5 } & Frequency & $\%$ & Frequency & $\%$ \\
\hline $\begin{array}{l}\text { Availability of needed input } \\
\text { Available }\end{array}$ & 109 & 34.06 & 209 & 65.31 \\
$\begin{array}{l}\text { Not available } \\
\text { Affordability of input }\end{array}$ & 211 & 65.94 & 112 & 35.00 \\
$\begin{array}{l}\text { Affordable } \\
\text { Not affordable }\end{array}$ & 122 & 38.13 & 132 & 41.25 \\
Accessibility to input & 198 & 61.87 & 188 & 58.75 \\
Accessible & 102 & 31.86 & 198 & 61.88 \\
Not accessible & 218 & 68.14 & 122 & 38.12 \\
Ownership of means of transport & & & & \\
Own & 98 & 30.63 & 98 & 30.63 \\
Do not own & 222 & 69.37 & 222 & 69.37 \\
No. of visits to input centre/mth & & & & \\
Once & 102 & 31.86 & 189 & 59.06 \\
Twice & 25 & 7.81 & 85 & 26.56 \\
Three times & 09 & 2.81 & 31 & 9.69 \\
More than three times & 0.0 & - & - & - \\
Not at all & 184 & 57.5 & 15 & 4.69 \\
\hline
\end{tabular}

Source: Field survey, 2013

Relationship between socio-economic characteristic and accessibility to agro-input centers The analysis in Table 7 reveals that sex is significantly related to accessibility to agroinput. This implies that the males may have more access to agro-input centre because of their physical make and because they are the head of households. Marital status and income were also significantly related to accessibility to agro-input. This indicates that respondents that are not married may have more time to visit agro-input centers than the married ones who may be busy with family chores. Income is significant to access to input. Farm size was significant at $\mathrm{P}<0.01$ level. Farm sizes according to the findings of many researchers do not mean that the big farms will be more productive than the small farms. Some authors opined that smaller farms are more productive and that the productivity of a farm whether big or small depends on many factors amongst which are use and types of inputs, land use intensity, size of farm, factor use intensities and many other factors. Ownership of means of 
transportation is another factor that can affect access to input centers. The farmer that own means of transportation can find it easier to access input either from private or government established input centers than those that do not own means of transport, though not in all cases. Time of visit to input centers can also be a criteria used for accessibility, more than half $(59.06 \%)$ of the respondents visited private input centers at least once in a month to procure input when compared to $30.63 \%$ that visited government input centers. This indicates that more farmers visited private input centers.

TABLE 7

Relationship between selected socio-economic characteristics and access to agro-input centers

\begin{tabular}{lllll}
\hline Parameters & $\chi^{2}$ & $d f$ & $P<0.05$ & Sig \\
\hline Sex & 29.507 & 1 & 0.000 & $\mathrm{~S}$ \\
Age & 7.834 & 4 & 0.098 & $\mathrm{NS}$ \\
Marital status & 10.973 & 2 & 0.004 & $\mathrm{~S}$ \\
Education status & 11.896 & 5 & 0.064 & $\mathrm{NS}$ \\
Income & 32.547 & 4 & 0.000 & $\mathrm{~S}$ \\
Farm size & 14.743 & 2 & 0.001 & $\mathrm{~S}$ \\
\hline
\end{tabular}

S: Significant, NS: Not significant

\section{Conclusion}

The study has shown that farmers patronize private input centers than government input centers because of the distance covered to these centers though farmers have access to these input centers but still cover long distance to procure input and at times according to respondents' submission, the inputs may not be available and this may affect time of planting, production cost as well as the overall output of the farmer. To break the cycle of high input price, low input demand, the need to stimulate a huge increase in input demand is critical. The government should, therefore, support farmers by locating agro-input centers closer to farmers and make the inputs available at subsidized rates to farmers as at when needed. This will reduce production costs as well as increase farmers' production thereby making food available and reducing poverty.

\section{REFERENCES}

Adetunmbi, J., Saka, J. O. \& Fato, B.F. (2010) Seed handling system and its implication on seed quality in South Western Nigeria. Journal of Agricultural Extension and Rural Development 2, $133-140$.

Carney, D. (1998) Charge Public and private roles in agricultural Services provision. Published by Oversees Development Institute. 1 - 20

Ekong, E. E. (2003) An introduction to rural sociology. Dove Educational Publisher, Uyo, Nigeria

FAO (1997) Production Yearbook, Rome, FAO

Federal Ministry of Agriculture and Rural Development (2016) The Agriculture Promotion Policy (2016 - 2020). Abuja, Nigeria: FMARD.

Gordon, A. \& Craig, C. (2001) Rural non-farm activities and povery alleviation in sub-Saharan Africa. Policy Series 14: Chathan, NRI, United Kingdom.

Kihara, S. (2007) Agro-dealer network to reach 1.6 million rural farmers in Africa with essential farm supplies. AGRA policy paper

Kumar, L. \& Misra, D. D. (2004) GIS based application for rural development - A policy warranted.

Okorji, N. C. (2001) Creating an enabling environ for increased agricultural production. In: Proceedings of the 16th Annual Zonal Research Extension, Farmers input, Linkage system (REFILS) workings. Southeast/South Zones of Nigeria. Enugu.

Okunola, A. M. (2016) Role of Legislature in Sustainable Agricultural Development in 
Developing Nations: A Case Study of Nigeria. Turkish Journal of Agriculture - Food Science and Technology 4 (5), $330-335$

Oyo State Agricultural Development (2000) Village listing survey in Oyo State, planning, monitoring and evaluation department, Oyo State Agricultural Development Project (OYSADEP) Saki.

Idachaba, F.S. (2006) Good intensions are not enough, collected essays on Government and Nigeria Agriculture, commodity taxes and farm input subsidies. University Press Plc, Ibadan.

Jibowo, (2005) History of agricultural extension in Nigeria. In S.F Adedoyin (Ed.) Agricultural extension in Nigeria. Agricultural Extension Society of Nigeria.

National Agricultural Research Project (1994) National Agricultural Research Strategy Plan. Draft report on North West Zone. Ibadan, Nigeria: NARP press.

National Bureau of Statistics (NBS) (2014) www. nigerianstat.gov.ng accessed on 25/08/2018.

Ofona, O.G, Efefion, E.C., \& Omini, E.E. (2016) Constraints to agricultural development in Nigeria. International Journal of Development and Economic Sustainability 4 (2), 19 - 33.
Ogbalubi, I.N. \& Wochocha, C.C. (2013) Agricultural development and employment generation: The Nigerian experience. JOSR Journal of Agriculture and Veterinary Science 2 (2), 60 69.

Omotayo, A. M. (2011) Sustainable extension delivery system in a changing economic and political environment: A keynote address delivered at the $24^{\text {th }}$ annual southwest REFILS held at the Institute of Agricultural Research and Training, Ibadan.

Oyegbami, A. (2014) Spatial distribution of agricultural extension units, input centers and their accessibility to farmers in Oyo State, Nigeria. An unpublished $\mathrm{PhD}$ thesis in the Department of Agricultural extension and Rural Development, Federal University of Agriculture, Abeokuta, Nigeria.

Phillip, D., Nkonya, E., Pender, J. \& Oni, O. A. (2009) Constraints to increasing agricultural productivity in Nigeria: A review. International Food Policy Research Institute. NSSP background paper 6 .

Yinusa, M. B. (1999) Not farms alone. A study of rural household in the middle belt of Nigeria DAREASC working paper 38. 